\title{
Using Projects to Improve Understanding of Introductory Thermal Science Concepts
}

\author{
Heather L. Cooper \\ Purdue University
}

\begin{abstract}
Engineering and technology students often struggle with comprehension of thermal science topics, due to the seemingly abstract nature of the topics when compared with materials or machine design concepts. For example, it is difficult for some students to "see" the conservation of thermal energy explained by the First Law of Thermodynamics, yet they can easily visualize transformations between potential and kinetic energy in a simple mechanical system. Laboratory experiments help alleviate the difficulties in some cases, but even a lab-based introductory thermal science course in the Mechanical Engineering Technology department at Purdue University does not consistently improve student understanding of the basic principles. This paper describes the development and implementation of simple open-ended projects, used in conjunction with the laboratory portion of the course, as a means for increased student understanding. Project topics have ranged from proving basic equations to investigating more complex problems, such as the effect of window treatments on cooling requirements or the feasibility of alternative energy sources. Results from Fall 2003 semester projects are presented.
\end{abstract}

\section{Introduction}

Many universities have implemented projects to enhance student learning in thermal science courses. A cursory search of recent activity in this area reveals an entire project-based thermodynamics course ${ }^{1}$ and projects in thermodynamic cycle optimization ${ }^{2}$. These are just two examples of the use of projects to improve understanding of thermal science concepts that are traditionally difficult for engineering and engineering technology students to grasp.

In the lab-based introductory thermal science course in the Mechanical Engineering Technology (MET) department at Purdue University, projects were first implemented in the Fall 2002 semester. It was desired to have the students demonstrate their overall knowledge of instrumentation and measurement of thermal systems, and their comprehension of the relationship between the theoretical concepts and physical systems. Rather than requiring students to perform a lab practical exam at the end of the semester based on the wide variety of laboratory experiments and analyses throughout the semester, projects were developed as an integrated approach to evaluate student learning in the lab portion of the course.

\section{Project Development}

The basic structure of the projects involves students working in small teams to complete a simple open-ended project over approximately twelve weeks. Table 1 outlines the typical project schedule and shows the deliverables at each stage. Week one of the project corresponds to the third week of the semester, during which the projects are introduced to the students and they complete a brainstorming session. In the fourth week of the project, students submit a detailed 
outline or chart of expected project tasks and schedule. A status report is due around week seven or eight, and the final project is completed in week twelve. The student teams present their work in two ways: with a fifteen-minute oral presentation, and with a poster. No written report is required.

Table 1. General project deliverables and schedule.

\begin{tabular}{|c|l|}
\hline WEEK & \multicolumn{1}{|c|}{ PROJECT ACTIVITY } \\
\hline 1 & $\begin{array}{l}\text { Introduction to projects } \\
\text { Brainstorming session on given project }\end{array}$ \\
\hline $2^{*}$ & Submit initial proposal of how project will be completed \\
\hline 4 & Submit detailed outline of project tasks and schedule \\
\hline $7-8$ & $\begin{array}{l}\text { Submit status report including work completed and plan } \\
\text { for remaining work }\end{array}$ \\
\hline $10^{*}$ & $\begin{array}{l}\text { Submit status report including preliminary results and } \\
\text { conclusions }\end{array}$ \\
\hline 12 & $\begin{array}{l}\text { Project presentations } \\
\text { Submit poster }\end{array}$ \\
\hline
\end{tabular}

*Added Fall 2003

In the Fall 2003 semester, two additional tasks were added (also shown in Table 1) to keep the students thinking about their projects more regularly and to keep them on track toward meeting project objectives. Now students are required to submit a proposal in the week immediately after their brainstorming session, and a second status report is due shortly before the conclusion of the project. During all semesters in which the projects have been implemented, some amount of laboratory time has been reserved for in-class project work.

The scope of the projects was kept small, to align with their contribution to the overall course grade. The project amounts to $25 \%$ of the laboratory grade, which is in turn $30 \%$ of the overall course grade. To keep the magnitude of each project manageable, each student team is given a specific project topic or system and one or two specific objectives, similar in complexity to a single lab experiment. A sampling of representative project titles and their associated objectives is shown in Table 2.

Table 2. Example projects and objectives.

\begin{tabular}{|c|l|}
\hline PROJECT TITLE & \multicolumn{1}{|c|}{ PRIMARY PROJECT OBJECTIVE } \\
\hline Hair Dryer Thermal Analysis & Determine the performance/efficiency of a hair dryer \\
\hline Window Treatment Analysis & $\begin{array}{l}\text { Determine the effect of window treatments on heat } \\
\text { transfer into a room }\end{array}$ \\
\hline Tire Pressure Analysis & $\begin{array}{l}\text { Demonstrate ideal gas law principles using an } \\
\text { automotive tire }\end{array}$ \\
\hline Fuel Cell System Analysis & $\begin{array}{l}\text { Evaluate performance/efficiency of a PEM fuel cell } \\
\text { system }\end{array}$ \\
\hline Light Bulb Comparison & $\begin{array}{l}\text { Compare thermal performance of fluorescent and } \\
\text { incandescent light bulbs }\end{array}$ \\
\hline Kohler Engine Analysis & $\begin{array}{l}\text { Determine effect of engine speed and load on exhaust } \\
\text { temperatures }\end{array}$ \\
\hline
\end{tabular}


To ensure that each project allows an open-ended approach to problem solving, the methodology taken to meet the objectives is the responsibility of the students. Guidelines are provided that require students to follow a systematic approach and to make the link between theoretical concepts and experimental results. Key components of the required approach are:

- Students must follow a process similar to the scientific method, including problem identification, hypothesis formation, experimentation, and conclusion development.

- Students must include a mathematical model and analysis and correlate their mathematical analysis to their experimental results

- Students must show at least two phases of experimentation where the second phase addresses unanswered questions from the results of the first phase

Within these guidelines, changes in specific project objectives are sometimes allowed, based on the interests of a particular project group.

\section{Project Implementation Challenges}

The most significant challenges in implementing these projects have been generating a set of meaningful projects each semester, and then managing those multiple projects across several laboratory divisions. Each semester, the introductory thermal science course has an enrollment of 65-75 students, which are divided into 16-20 individual lab teams in 4-5 laboratory divisions. In the first two semesters in which the projects were delivered, each lab group was given their own specific project topic, for a total of 16-20 distinct projects. The initial list of topics was a combination of existing experiments no longer in use in the course and ideas on how to demonstrate specific theoretical concepts not already covered by one of the lab sessions, plus several topics that could best be described by the phrase, "I wonder what happens if...." The benefit to this approach is that the instructors (faculty and teaching assistant) were able to observe in a short amount of time which types of projects seemed appropriate for the students. The obvious disadvantage is that the instructors needed to spend a tremendous amount of time managing the projects, in order to provide relevant feedback to the students on each individual project.

In the Fall 2003 semester, each laboratory division was given a single project title and basic objectives. Then each lab team within that division was allowed to focus on a slightly different approach to the same given project. This revised approach reduced the total number of projects to four (from a possible 16 in the fall semester), which allowed the instructors to provide better feedback throughout the project timeframe, and also will limit repetition of projects in later semesters.

Another challenge has been to provide the students with guidelines that ensure a systematic approach while still allowing enough control over the methodology to learn something new. Addressing this issue is an ongoing process, and slight modifications have been made each semester to the project handout to reflect changes in the guidelines. It is expected that some of the guidelines will ultimately be adjusted to correspond more to broader engineering experimental design techniques and processes ${ }^{3}$, rather than the scientific method. 


\section{Detailed Project Results}

Two of the more interesting student projects listed in Table 2 were the projects entitled Hair Dryer Thermal Analysis and Fuel Cell System Analysis. Some version of the hair dryer project was used in each of the Fall 2002, Spring 2003, and Fall 2003 semesters, and has not yet produced a "successful" outcome. The fuel cell project was new in the Fall 2003 semester, and resulted in very distinct and creative approaches. Both are described in more detail below.

\section{$\underline{\text { Hair Dryer Thermal Analysis }}$}

In the hair dryer project, each lab team was given a hairdryer, and was provided access to an identical hair dryer that could be disassembled as needed. The objectives of the project were to evaluate thermal performance of the hair dryer with respect to the First Law of Thermodynamics and to determine the efficiency of the hair dryer. Efficiency was defined in general terms as the ratio of desired output to required input.

This project proved to be one of the most challenging for students. Most teams were able to identify links between measurements of the hair dryer during operation and the individual terms of the First Law of Thermodynamics for steady flow systems. They successfully related the electrical power input to the work term, the air velocity to the kinetic energy term, and the air temperature to the enthalpy term. However, reasonable efficiency results were not obtained by any of the lab teams. Students were not sure what quantities should be included in the "desired output" for the efficiency calculation, and they struggled with defining appropriate boundaries for the system so that all inputs and outputs could be measured. The majority of the students who were assigned this project recognized that a hair dryer is inherently inefficient, but calculated very high or even impossible efficiency values. By the end of the project, many did understand that their measurement and analysis assumptions have a significant effect on the outcomes.

\section{$\underline{\text { Fuel Cell System Analysis }}$}

The fuel cell project was an excellent demonstration of student creativity, since each of the four groups assigned the project chose a unique approach. The students were given product specifications for a residential-scale, natural gas powered PEM (proton exchange membrane) fuel cell power plant with cogeneration capabilities. The given system is designed to operate on natural gas, which is reformed to extract hydrogen gas. The hydrogen fuels the PEM fuel cell stack, which produces electrical power output through a catalyzed chemical reaction. If installed with a cogeneration or heat recovery loop, the system can also be used to provide supplemental water heating. The basic objectives of the project were to evaluate the performance of the system and to determine its efficiency. In this case, the efficiency was published in the specifications, so it was up to the students to determine the specific scope and detailed approach to the project.

This project was somewhat unusual for MET students in a laboratory setting, in that there was no physical hardware available for their use; it was solely a theoretical analysis. For this reason, the students who were assigned this project were initially very intimidated. Once their research produced enough information to get started, the resulting solutions were quite impressive. 
One group chose to verify the published efficiency of the fuel cell system by analyzing the system components in detail. They performed a chemical analysis on the fuel reforming process to determine the amount of hydrogen gas produced by the specified input flow of natural gas. The efficiency was determined from the specified electrical output of the system and the energy content of the calculated hydrogen gas flow. After a few iterations of their assumptions, the group successfully verified the published efficiency of the system, and learned a lot about both chemical energy conversion and hydrogen usage in a typical residential-scale PEM fuel cell system.

A second group also focused on the natural gas reformer, but chose to research different types of reformers and reforming processes to determine if the reformer used in the fuel cell system was the most efficient available. The output from this group lacked substantial engineering analysis, but still illustrated an alternative approach to the project.

A third group decided to compare the fuel cell system to an existing internal combustion engine and generator system for which they had found specifications during their online research. The goal was to determine which system would be more efficient when used in conjunction with heat recovery, so they would be analyzing both fuel to electric efficiency as well as heat recovery efficiency. They determined that the engine/generator and fuel cell systems had approximately equivalent efficiencies without heat recovery, but that the fuel cell system was significantly more efficient than the engine/generator system when heat recovery was taken into account. Through this comparison, they effectively confirmed for themselves and the rest of the lab class the difference between single component efficiency and overall system efficiency.

The fourth group became completely frustrated with the lack of published information available on the system they were studying, and decided to change the outcomes of the project (with instructor approval). Rather than focusing on efficiency, they performed a cost analysis of the system based on required natural gas consumption, and compared costs with a gasoline powered generator with similar electrical output. They determined that, for the same electrical power output, the natural gas PEM fuel cell system would cost almost $100 \%$ more per hour to operate than the chosen gasoline generator. The hardware and installation cost is also extremely high for the fuel cell system. During their final presentation of these results, they questioned the usefulness of the new technology, which led to an engaging class discussion on current issues regarding the future of hydrogen and fuel cell technologies.

\section{Student Feedback}

Student feedback has been positive since the initial implementation of the projects. In the Fall 2003 semester, surveys were completed at the end of the project. The survey questions asked what the student liked best and least about the project, and whether the project gave the student a better understanding of any course concepts. (Students who answered yes to the latter question were asked to list the specific concept(s).) Table 3 lists a few of the individual student responses to the question regarding course concepts. It is important to note that this list of concepts is from students who completed four different projects, but it clearly demonstrates that students feel the projects have enhanced their learning of thermal science concepts. 
Table 3. Concepts in which projects improved understanding.

\begin{tabular}{|c|}
\hline First Law of Thermodynamics \\
\hline Enthalpy \\
\hline Systems, boundaries \\
\hline Efficiency \\
\hline Mass flow rate \\
\hline Heat recovery \\
\hline Power generation \\
\hline Steam power plant \\
\hline Ideal gas law \\
\hline Industrial applications \\
\hline Convection heat transfer \\
\hline Work, heat transfer \\
\hline Closed systems \\
\hline Horsepower \\
\hline Otto Cycle \\
\hline Conservation of energy
\end{tabular}

\section{Conclusions}

Simple, open-ended projects have been implemented successfully to enhance student comprehension of basic thermal systems concepts in a lab-based introductory thermal science course. The projects provide mechanical engineering technology students with an opportunity to apply basic concepts to new systems not already covered in the existing laboratory experiments, and allow them to gain practice in designing their own experimental and analytical processes. Initial implementation of the projects has produced favorable results, both from the student and instructor perspectives. Similar projects can easily be implemented at other institutions using available or low-cost equipment to help students understand basic thermal science concepts.

\section{References}

1. Roy, S., Nasr, K.J. and Berry, K.J. (2002), Development of a project-based and design-driven thermodynamics course [CD-ROM]. Proceedings of the 2002 American Society for Engineering Education Annual Conference and Exposition, Montreal, Quebec.

2. DeJong, N. (2002), Teaching cycle optimization in introductory thermodynamics courses [CD-ROM]. Proceedings of the 2002 American Society for Engineering Education Annual Conference and Exposition, Montreal, Quebec.

3. Holman, J.P. (2001), Experimental Methods for Engineers, $7^{\text {th }}$ ed., Boston, MA: McGraw-Hill.

\section{Biography}

HEATHER L. COOPER, P.E.

Heather L. Cooper is an Assistant Professor of Mechanical Engineering Technology at Purdue University. She teaches courses in thermal science and machinery diagnostics, with applied research interests in alternative energy education. She has seven years of product engineering experience at General Motors Corporation, including extensive work in noise and vibration, and is a member of ASEE, SAE, and ASME. 